\title{
RESEARCHING FACTORS OF INNOVATIVE ACTIVITIES OF AGRARIAN BUSINESS OF UKRAINE UNDER GLOBALIZATION OF THE WORLD ECONOMY
}

\begin{abstract}
Modern processes of reforming the agroindustrial complex of Ukraine, a large part of which belongs to the agrarian sector, under the globalization of world economic processes in the agricultural market require that domestic agroindustrial enterprises improve and rationally manage innovative activities (IA). The effective solution of problems that arise in this context in the rapidly changing economic and social and political environment requires that analytical methods in the management of the enterprises of the agroindustrial complex (AIC) be used on the basis of the tools of economic and mathematical modelling, taking into account characteristics of agrarian production. The main approaches to modelling systems related to IA management are either descriptive or insufficiently formalized, and suggest virtual experimenting with IA management, avoiding the possibility of assessing the impact and consequences of different management options in the long view, minimizing IA risks when making managerial decisions. The subject matter of the article is the tools of economic and mathematical simulation of the development of innovative activities of the domestic agroindustrial complex. The goal is to develop tools for modelling innovative activities of enterprises of the agroindustrial complex of Ukraine in the form of analytical dependencies of impact factors. The objective is to research the dynamics of innovative activities of enterprises of the agroindustrial complex of Ukraine in terms of its components under the globalization of world economic processes in the market of agricultural products. General scientific methods are used, such as system analysis - to determine the peculiarities of development of IA of agroindustrial production in Ukraine, factor analysis - to formalize the cause-and-effect relationships of the investigated factors of AIC enterprises impact on IA. The following results were obtained: on the basis of the analysis of the dynamics of changes in the major indices of domestic agricultural production, the problem aspects were identified and the components of IA of agricultural production were determined, latent factors with prolonged impact on the level of innovative activities of agricultural enterprises of Ukraine were calculated. Conclusions: the calculated latent factors of the impact of AIC enterprises on IA can be efficiently used in foreign economic activities as recommendations for determining the IA strategy of Ukraine in the world agricultural market.
\end{abstract} factors.

Keywords: innovative activities, world economy, agroindustrial production, agricultural products, development factors, latent

\section{Problem setting}

The future of Ukraine, which is one of the most resource-rich countries in the world, largely depends on the effective development of agricultural management. The global food crisis is growing every year, the economic and financial crisis in Ukraine and abroad is spreading, world natural resources are depleting, the ecological situation is degrading as evidenced by climate changes and the decline of health and living standards of the world population. These and other factors testify the need of IA intensification as one of the most efficient ways to increase the competitiveness of the country under the globalization of world economic processes in the agricultural market.

Domestic agroindustry has a significant innovative potential, which is capable to ensure a high level of scientific and technological development of Ukraine in the international business environment. At the same time, the reserves of production capacities and favorable foreign economic environment still remain the prevailing sources of growth in the sphere of agroindustry for the export of agricultural raw materials to international markets of agricultural products. Maintaining current tendencies in the agroindustrial sector of the country which are based on low-tech production as well as the ongoing decline of production in the field of agroindustrial complex proves the necessity of applying scientific approaches to IA introduction and management at AIC enterprises [1]. Today one of the priorities of the state policy should be the modernization of both the national industry in general and the agroindustrial complex in particular, on the basis of IC intensification, and the efficient use of its powerful scientific and technological potential. At the present stage it is necessary to implement complex measures to support innovative activities of domestic enterprises, including agricultural enterprises, at all stages of IA, to stimulate the demand for research results and innovative developments, for qualified personnel, as well as for favorable conditions for producing innovative products with a high degree of added value.

\section{The analysis of literary sources and recent researches}

The analysis of innovative activities is characterized by creating, developing and spreading innovations. So far, the concept of "innovation" has aroused much interest among scientists around the world. The research on this issue was initiated mainly by European and American scholars such as I. Perlaki [2], E. Rogers [3], B. Santo [4], B. Twice [5], J. Schumpeter [6] and others. Although the concept of "innovation" emerged abroad at the beginning of the XX century, domestic scientists analyzed and further developed it in the $1930 \mathrm{~s}$, but more attention to this problem began to be paid in the 1960s when the issue of the essence of innovation was more widely studied.

The concept of "IA management", a set of measures supporting innovations, tools for strategic planning of enterprise IA, the most important managerial problems related to the management of innovation were studied in foreign sources of information to determine the state of IA management outside Ukraine. According to numerous scientific literary sources, the interest to the development and management of innovation in the world has grown enormously over the last few years, which attracts the scientific attention of managers and scientists. [7, 8]. New approaches to the introduction of innovation by using achievements in the field of information and 
communication technologies have become a catalyst for spreading innovative technologies, innovative products and other elements of IA. Such scientists as S. Zott, R. Amit and L. Massa [9] have developed and distributed the concept of business-modelling innovations (BMI) with the help of Internet resources. D.J. Teece states that BMI is an integral part of the economic behavior of the management entity [10].

The analysis showed that innovative technologies come with new ways of doing business $[11,12]$. There are two major approaches: 1) the use of post-industrial technologies; and 2) corporate sector efforts to enter new markets and attract new customers. Scientific and technological advances in so-called post-industrial technologies (for example, software or biotechnology) come with the development of organizational methods and management structures that fundamentally differ from traditional manufacturing organization and come with new ways of doing business. [13].

The second approach in the form of institutionalization of open innovation as a way of arranging IA outside the enterprise is typical for many branches of industry [14]. In addition, it should be stated that while "correct" product design is a prerequisite for entering new markets, IA management is crucial for allocating resources and adjusting sales channels that are necessary for the success of business operations. Thus, special attention is paid to organizational and managerial forms of IA development in the context of modern foreign enterprises operation.

But, despite a significant number of publications, the role and strategic position of Ukraine in the sphere of innovative activities in the world agricultural market is still an issue of present interest that requires further researching.

The goals of the article are to research the development of innovative activities of AIC enterprises of Ukraine and their main components in the global agricultural market on the basis of determining factors that have impact on the level of innovative activities of agroindustrial enterprises and to model latent factors that affect the indices of the dynamics of innovativeness of domestic agricultural enterprises.

\section{Presentation of the material}

Achieving the competitiveness of the Ukrainian economy, where the competitiveness of domestic products and services in domestic and foreign markets plays a special part, is one of the main tasks of economic science. An important element of competitiveness is innovations that have recently become crucial for developing agrarian production, which is based on the gained knowledge and information resources. The increasing degree of openness of the Ukrainian economy and strengthening integration processes in the world economy in order to overcome food security require adequate responses from Ukrainian agroprocessing enterprises.

Solving the task of the food security problem in Ukraine is a national task that is directly related to IA development in the agroindustrial complex. Ukraine has declared the selection of an innovative way of its development. To implement this program, a large number of legislative and regulatory documents have been adopted, specialists actively work on the issue of reorganization in government bodies, hold conferences, forums, and public discussions, and consider innovations in numerous publications. But the main task is launching real mechanisms of innovative development that will work in every area of the national economy, taking into account national priorities and trends of world development of scientific and technological progress.

Let us analyze the dynamics of introducing innovations by enterprises of the agroindustrial complex of Ukraine on the basis of statistical information (Fig. 1) [15].

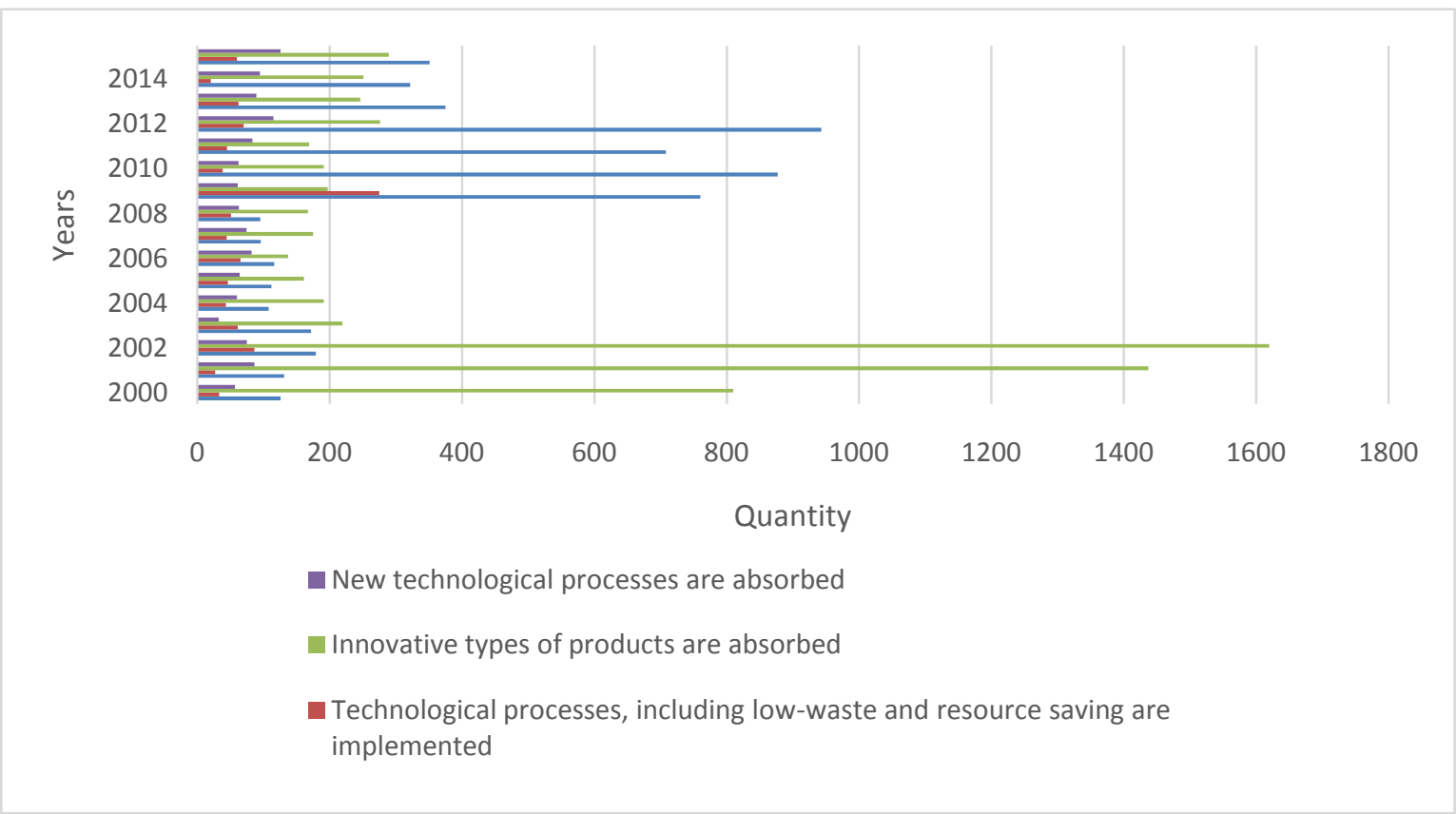

Fig. 1. Dynamics of introducing innovations by enterprises of the agroindustrial complex of Ukraine (2000-2015) 
According to the results of the analysis, it can be concluded that, unfortunately, the number of innovations introduced by domestic enterprises of the agroindustrial complex, with the general tendency to increase, has decreased over the last years.
The dynamics of the costs for introducing innovations by enterprises of the agroindustrial complex of Ukraine is presented in fig. 2.

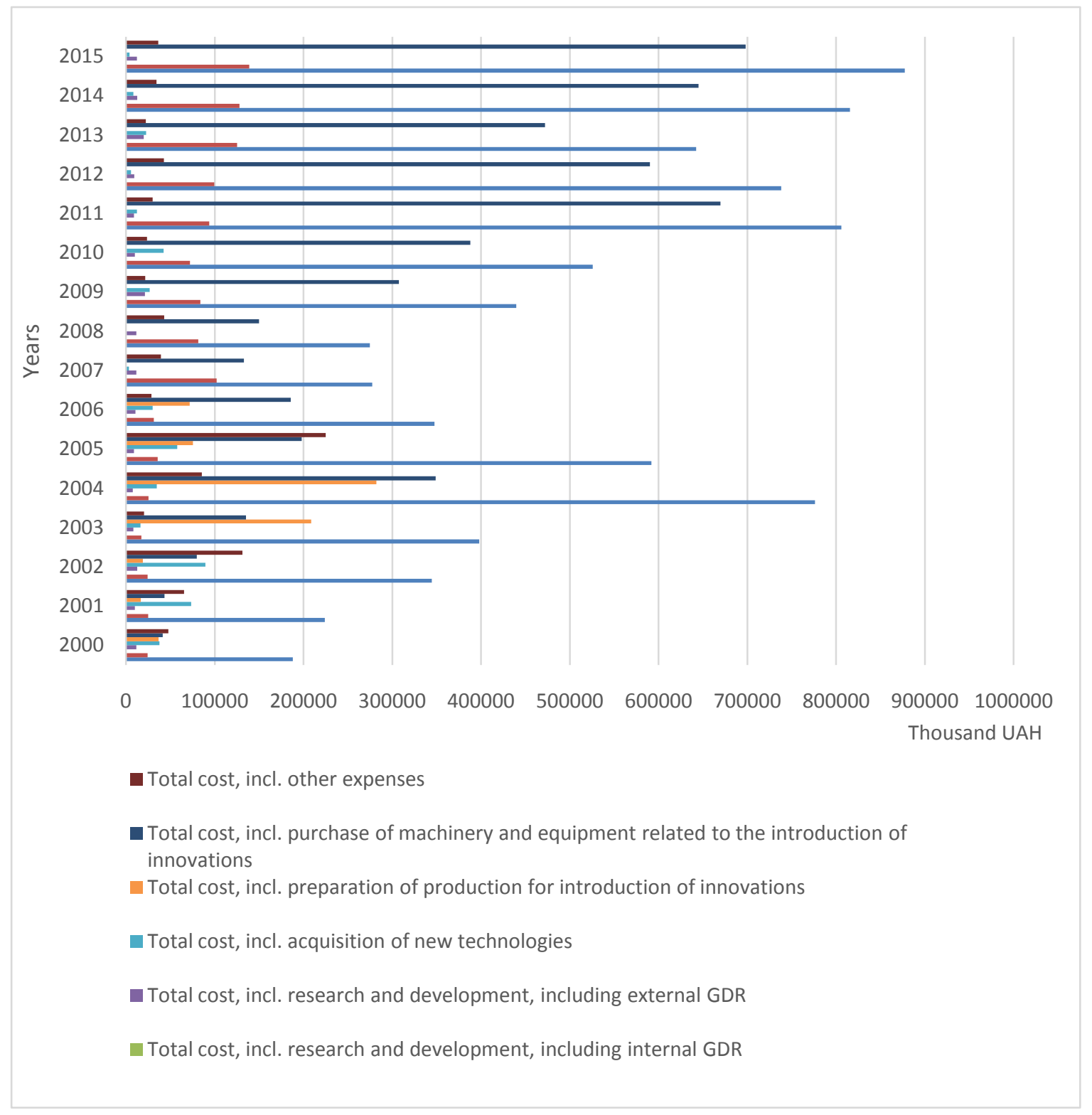

Fig. 2. The dynamics of costs for introducing innovations by enterprises of the agroindustrial complex of Ukraine (2000-2015)

The dynamics of attracted investments by enterprises of the agroindustrial complex of Ukraine over the last fifteen years according to the sources of financing is presented in Fig. 3.

The method of multidimensional statistical analysis (factor analysis) is used to study the factors of impact on the IA level of enterprises of the agroindustrial complex in terms of its components. This analysis is intended to identify and quantify generalizing characteristics that adequately describe the whole set of output and result indices, thereby reflecting the laws of the development of the enterprise research activities and the mechanism of their internal interconnections. The calculations were performed taking enterprises of the agroindustrial complex of Ukraine as an example with the help of Statgraphics Centurion statistical package.

To develop the system of models of latent factors that affect the IA components of the enterprises of Ukraine, the integral indices that characterize the IA components of AIC enterprises should be calculated, namely: 1) the dynamics of the innovative activity of enterprises, 2) the dynamics of IA costs and sources of financing, 3) the dynamics of implementing the IA of enterprises. Each component is characterized by a system of individual indices [16]. 


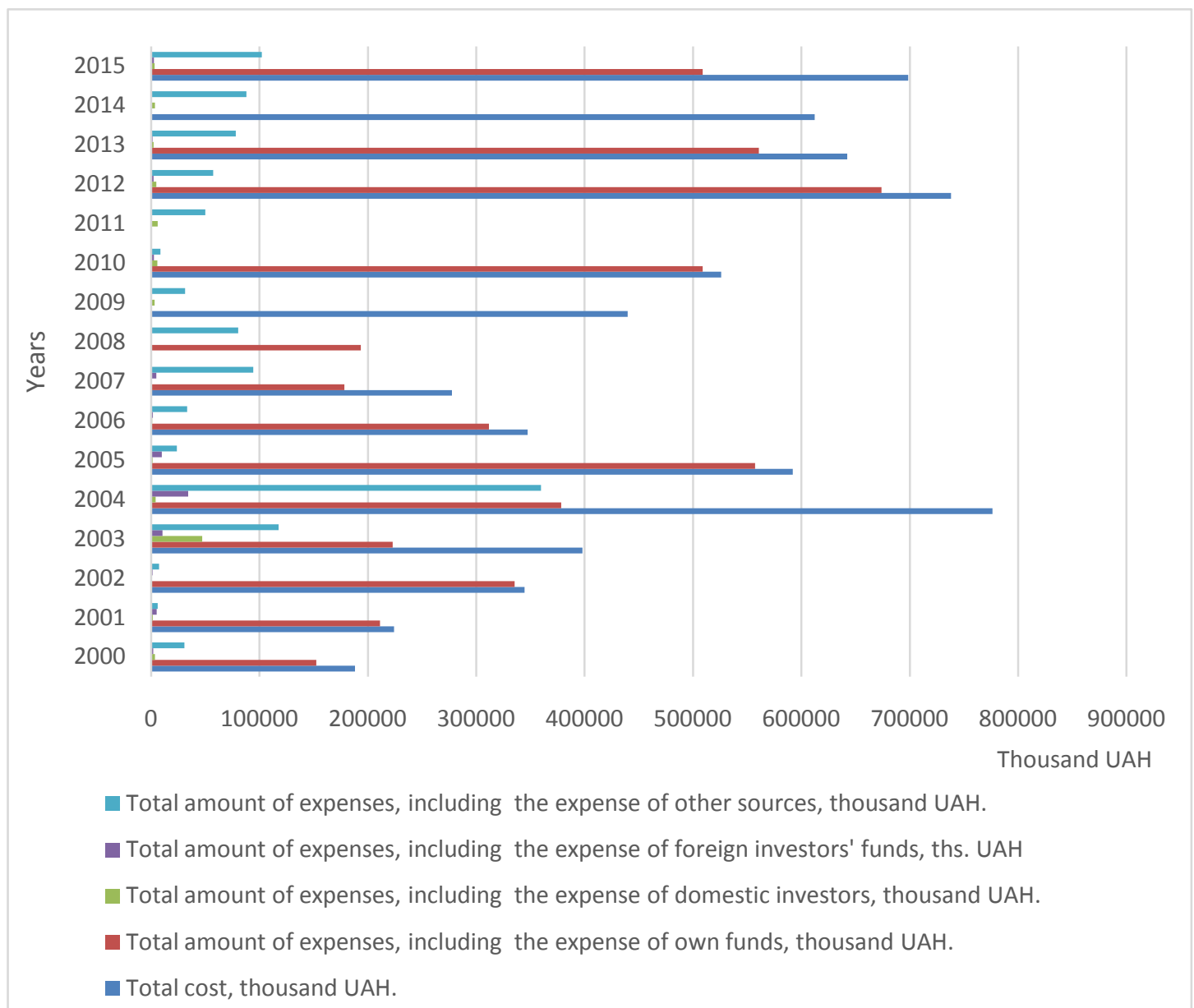

Fig. 3. Dynamics of attracted investments by enterprises of the agroindustrial complex of Ukraine according to the sources of financing (2000-2015)

Thus, the dynamics of innovative activities of enterprises is described by the following indices: $x_{1}$ is enterprises engaged in innovations; $x_{2}$ is the total expenses of the enterprises engaged in innovations; $x_{3}$ is the research and development costs; $x_{4}$ is the expenses on internal research activities; $x_{5}$ is the expenses on external research activities; $x_{6}$ is the cost of acquiring new technologies; $x_{7}$ is the cost of preparing an enterprise for the introduction of innovations; $x_{8}$ is the cost of purchasing machinery and equipment related to the introduction of innovations; $x_{9}$ is other costs related to the introduction of innovations.

The second component, that is the dynamics of costs and sources of financing of enterprise IA, depends on the following indices: $x_{10}$ is the total expenses; $x_{11}$ is the amount at the enterprise own expense; $x_{12}$ is the amount at the expense of domestic investors; $x_{13}$ is the amount at the expense of foreign investors; $x_{14}$ is the amount at the expense of other sources.

Assessing the dynamics of the implementation of enterprise IA, which is the third component, is characterized by the following indices: $x_{15}$ is the share of enterprises that introduced innovations; $x_{16}$ is a number of new technological processes introduced; $x_{17}$ is a number of new low-waste, resource-saving processes implemented; $\mathrm{x} 18$ is a number of innovated types of products; $\mathrm{x} 19$ is a number of innovated types of equipment; $\mathrm{x} 20$ is the share of innovated production realized by an enterprise on an industrial scale.

The first component of the level of IA of Ukrainian enterprises, that is the dynamics of innovative activities of enterprises, is affected by several factors. Let us consider these factors in groups of three. They account for $73.67 \%$ of the variability of indices that determine this component. Latent factors affecting the indices of the dynamics of innovative activities of domestic enterprises are described by the following equations:

$$
\begin{aligned}
F_{11} & =0,705 x_{11}+0,217 x_{12}-0,023 x_{13}+0,094 x_{14}+0,152 x_{15}+ \\
& +0,771 x_{16}+0,377 x_{17}-0,747 x_{18}+0,857 x_{19}-0,931 x_{20}, \\
F_{12} & =0,549 x_{11}-0,634 x_{12}-0,195 x_{13}-0,201 x_{14}+0,766 x_{15}+ \\
& +0,366 x_{16}-0,213 x_{17}+0,282 x_{18}+0,927 x_{19}+0,075 x_{20}, \\
F_{13} & =0,077 x_{11}+0,029 x_{12}+0,918 x_{13}+0,909 x_{14}-0,026 x_{15}- \\
& -0,300 x_{16}-0,428 x_{17}-0,292 x_{18}-0,090 x_{19}+0,085 x_{20} .
\end{aligned}
$$

Thus, in the whole set of enterprises the first, and consequently, the most significant factor is the generalizing one (the first factor), created by indices, formed in the direction of reducing factor loads: $x_{20}, x_{19}, x_{16}, x_{18}, x_{11}$, the rest of the indices can be 
neglected because their factor loads are less than 0.5 . The second factor is indices $x_{19}, x_{15}, x_{12}, x_{11}$. The third factor of the state of the innovative activities of enterprises of Kharkiv region is characterized by the following sequence of indices: $x_{13}, x_{14}$. Thus, as a result of the conducted analysis, the first three latent factors that influence the dynamics of innovative activities of enterprises were obtained; they are $-x_{20}, x_{19}, x_{13}$.

The second component of the enterprise IA, that is the dynamics of IA costs and sources of financing, are affected by several factors as well. So, the latent factors will also be considered in groups of three; their equations are as follows:

$$
\begin{aligned}
& F_{21}=0,902 x_{1}+0,203 x_{2}+0,925 x_{15}+0,382 x_{16}-0,112 x_{17}+0,536 x_{18}+0,787 x_{19}, \\
& F_{22}=-0,311 x_{1}+0,864 x_{2}+0,125 x_{15}+0,611 x_{16}-0,018 x_{17}-0,778 x_{18}+0,308 x_{19}, \\
& F_{23}=-0,151 x_{1}-0,024 x_{2}+0,135 x_{15}+0,558 x_{16}+0,959 x_{17}-0,060 x_{18}-0,049 x_{19} .
\end{aligned}
$$

The ranking of indices according to these factors is: $x_{15}, x_{2}, x_{17}$. The second group of three factors accounts for $85.489 \%$ of the variability of the indices that determine this component.

The third component of the level of the IA of agricultural enterprises of Ukraine, that is the dynamics of implementing IA is also affected by three factors, which accounts for $81,84 \%$ of the variability of indices that determine this component. The equations of this group of latent factors are:

$$
\begin{aligned}
F_{31}= & 0,944 x_{1}+0,042 x_{2}+0,109 x_{3}+0,887 x_{15}+ \\
& +0,261 x_{16}-0,112 x_{17}+0,668 x_{18}+0,719 x_{19}, \\
F_{32} & =-0,179 x_{1}+0,796 x_{2}+0,781 x_{3}+0,309 x_{15}+ \\
& +0,689 x_{16}+0,042 x_{17}-0,690 x_{18}+0,484 x_{19}, \\
F_{33} & =-0,138 x_{1}-0,128 x_{2}+0,234 x_{3}+0,113 x_{15}+ \\
& +0,485 x_{16}+0,955 x_{17}+0,002 x_{18}-0,077 x_{19} .
\end{aligned}
$$

Therefore, there are the 7th, 8th and 9th latent factors that affect the dynamics of the implementation of enterprise IA, whose ratings of indices have the following sequence: $x_{1}, x_{2}, x_{17}$.

\section{Conclusions}

The factors that affect the level of IA of agricultural enterprises in terms of their components were investigated in order to show the laws and patterns of developing the IA of the agroindustrial complex of Ukraine and the mechanisms of their internal and external interrelations; the factor analysis was performed as well. With the help of the analysis results, the system of models of latent factors that affect the IA components was developed on the basis of computed integral indices that characterize the components of their IA, in particular, the dynamics of innovative activities of enterprises, the dynamics of IA costs and sources of financing, the dynamics of implementing the enterprise IA. The latent factors that have been determined according to the three components of IA of agricultural enterprises can be efficiently used in foreign economic activities as recommendations for determining the IA strategy of Ukraine in the world agricultural market.

\section{References}

1. Babenko, V. (2014), Management of innovation processes of processing enterprises of agrarian and industrial complex (mathematical modeling and information technologies): monograph [Upravlinnya innovatsiynymy protsesamy pererobnykh pidpryyemstv APK (matematychne modelyuvannya ta informatsiyni tekhnolohiyi): monohrafiya], V. Dokuchaev Kharkiv National Agrarian University, Machulin, $380 \mathrm{p}$.

2. Blazhey, A., Driensky, D., Perlaki, I., Ed. Savelyev, A. Ya. (1988), Scientific and Technical Revolution and Engineering Education: [trans. from Slovaks.]. Moscow: High. School. 284 p.

3. Rogers, E., Agarwal-Rogers, R. (1980), Communication in the organization. Moscow: Economics. 176 p.

4. Santo, B., Ed. and intro Sazonova, B. B. (1990), Innovation as a mean of economic development: [trans. from hung.]. Moscow: Progress. 296 p.

5. Twis, B. (1989), Management of scientific and technical innovations: trans. from Englis. Moscow: Economics. 271 p.

6. Schumpeter, Y. A. (2007), The Theory of Economic Developmen. Moscow: Direct-Media. 400 p.

7. Baden-Fuller, C., Morgan, M. S. (2010), "Business Models as Models". Long Range Planning. No. 43. P. 156-171.

8. Johnson, M. W. (2010), Seizing the white space. Business Model Innovation for growth and renewal. Harvard Business Press: Boston, Massachussetts.

9. Amit, R., Zott, C. (2012), "Value Through Business Model Innovation". MIT Sloan Management Review. No. 53 (3). P. $41-49$.

10. Teece, D. J. (2010), "Business models, business strategy and innovation". Long Rang Planning. No. 43. P. 172-194.

11. Strunz Herbert (2011), Tagebuch der Weltwirtschaft, 2000-2010: Kommentare, Kritik, Reflexionen. Frankfurt-Moscow: Lang. $205 \mathrm{p}$.

12. World economic outlook, September 2011: slowing growth, rising risks. Intern. Monetary Fund. Washington: IMF. 2011. XVIII. $219 \mathrm{p}$.

13. Babenko, V. O. (2016), "Problematic aspects of innovative activity of Ukraine on the world market of agricultural products". Scientific Bulletin of Uzhgorod National University. "International economic relations and world economy". Issue 6. p. 1. P. 2629.

14. World economic outlook, April 2015: recovery strengthens, remains uneven. Intern. Monetary Fund. Washington: IMF. 2015. XVI. 216 p.

15. Science, Technology and Innovation. State Statistics Service of Ukraine. Available at: http://www.ukrstat.gov.ua. 
16. Babenko, V. A. (2017), "Modelling of factors affecting innovational agricultural activity of enterprises AIC in Ukraine". Scientific bulletin of Polissia. No. 1 (9). p. 2. P. 115-121.

Receive 11.09.2017

Відомості про авторів / Сведения об авторах / About the Authors

Сідоров Вадим Ігоревич - кандидат економічних наук, професор, Харківський національний університет імені В.Н. Каразіна, декан факультету міжнародних економічних відносин та туристичного бізнесу, м. Харків, Україна; e-mail: irtb@karazin.ua; ORCID: 0000-0002-5655-2221.

Сидоров Вадим Игоревич - кандидат экономических наук, профессор, Харьковский национальный университет имени В.Н. Каразина, декан факультета международных экономических отношений и туристического бизнеса, г. Харьков, Украина; e-mail: irtb@karazin.ua; ORCID: 0000-0002-5655-2221.

Sidorov Vadim - PhD (Economics), Professor, V.N. Karazin Kharkiv National University, Dean of the School of International Economic Relations and Travel Business, Kharkiv, Ukraine; e-mail: irtb@karazin.ua; ORCID: 0000-0002-5655-2221.

Бабенко Віталіна Олексіївна - доктор економічних наук, кандидат технічних наук, доцент, Харківський національний університет імені В.Н. Каразіна, професор кафедри міжнародного бізнесу та економічної теорії, м. Харків, Україна; e-mail: vitalinababenko@karazin.ua; ORCID: 0000-0002-4816-4579.

Бабенко Виталина Алексеевна - доктор экономических наук, кандидат технических наук, доцент, Харьковский национальный университет имени В.Н. Каразина, профессор кафедры международного бизнеса и экономической теории, г. Харьков, Украина; e-mail: vitalinababenko@karazin.ua; ORCID: 0000-0002-4816-4579.

Babenko Vitalina - Doctor of Sciences (Economics), PhD (Engineering Sciences), Associate professor, V.N. Karazin Kharkiv National University, Professor of the Department of International Business and Economic Theory, Kharkiv, Ukraine; e-mail: vitalinababenko@karazin.ua; ORCID: 0000-0002-4816-4579.

Бондаренко Михайло Ігорович -Харківський національний університет імені В.Н. Каразіна, аспірант кафедри міжнародних економічних відносин, м. Харків, Україна; e-mail: mib2435@gmail.com; ORCID: 0000-0002-2460-3848.

Бондаренко Михаил Игоревич - Харьковский национальный университет имени В.Н. Каразина, аспирант кафедры международных экономических отношений, г. Харьков, Украина; e-mail: mib2435@ gmail.com; ORCID: 0000-0002-2460-3848.

Bondarenko Michael - V.N. Karazin Kharkiv National University, Post-graduate student of the Department of International Economic Relations, Kharkiv, Ukraine; e-mail: mib2435@gmail.com; ORCID: 0000-0002-2460-3848.

\section{ДОСЛІДЖЕННЯ ФАКТОРІВ РОЗВИТКУ ІННОВАЦІЙНОЇ ДІЯЛЬНОСТІ АГРОПРОМИСЛОВОГО ВИРОБНИЦТВА УКРАЇНИ В УМОВАХ ГЛОБАЛІЗАЦЇ̈ СВІТОВОГО ГОСПОДАРСТВА}

Сучасні процеси реформування галузі АПК України, значна частка якої належить аграрному сектору, в умовах глобалізації світогосподарських процесів на ринку сільськогосподарської продукції вимагає від вітчизняних агропромислових підприємств вдосконалення та раціонального управління інноваційною діяльністю (ІД). Ефективне вирішення виникаючих при цьому завдань в швидко змінюваних умовах економічного та соціально-політичного середовища потребує застосування аналітичних методів в управлінні ІД підприємств АПК на основі інструментарію економіко-математичного моделювання 3 урахуванням особливостей аграрного виробництва. Основні підходи щодо моделювання систем, пов'язаних 3 управлінням ІД, здійснено описовими засобами або представлено 3 недостатньою формалізацією, i пропонують практично експериментувати з управлінням ІД, уникаючи можливість оцінити результативність та наслідки різних варіантів управління ІД в майбутній перспективі з мінімізацією ризиків ІД при прийнятті управлінських рішень. Предметом дослідження в статті $\epsilon$ інструментарій економіко-математичного моделювання розвитку ІД вітчизняного агропромислового виробництва. Мета полягає у розробці інструментів моделювання розвитку ІД підприємств АПК України у вигляді аналітичних залежностей факторів впливу. Завдання: дослідження динаміки розвитку ІД підприємств АПК України в розрізі її складових в умовах глобалізації світогосподарських процесів на ринку сільськогосподарської продукції. Використовуються загальнонаукові методи: системний аналіз - для визначення особливостей розвитку ІД агропромислового виробництва України, факторний аналіз для формалізації причинно-наслідкових взаємозв'язків досліджуваних факторів впливу на ІД підприємств АПК. Отримано такі результати: на основі проведеного аналізу динаміки змін основних показників вітчизняного агровиробництва виявлено проблемні аспекти та визначено складові ІД агропромислового виробництва, а також обчислено латентні фактори, що мають пролонгований вплив на рівень ІД підприємств АПК України. Висновки: обчислені латентні фактори впливу на ІД підприємств АПК доцільно використовувати у зовнішньоекономічній діяльності у якості рекомендацій для визначення стратегії ІД Україні на світовому ринку сільськогосподарської продукції.

Ключові слова: інноваційна діяльність, світове господарство, агропромислове виробництво, сільськогосподарська продукція, фактори розвитку, латентні фактори.

\section{ИССЛЕДОВАНИЕ ФАКТОРОВ РАЗВИТИЯ ИННОВАЦИОННОЙ ДЕЯТЕЛЬНОСТИ АГРОПРОМЫШЛЕННОГО ПРОИЗВОДСТВА УКРАИНЫ В УСЛОВИЯХ ГЛОБАЛИЗАЦИИИ МИРОВОГО ХОЗЯЙСТВА}

Современные процессы реформирования отрасли АПК Украины, значительная часть которой принадлежит аграрному сектору, в условиях глобализации мирохозяйственных процессов на рынке сельскохозяйственной продукции требует от отечественных агропромышленных предприятий совершенствования и рационального управления инновационной деятельностью (ИД). Эффективное решение возникающих при этом задач в быстро меняющихся условиях экономического и социально-политического среды требует применения аналитических методов в управлении ИД предприятий АПК на основе инструментария экономико-математического моделирования с учетом особенностей аграрного производства. Основные подходы к моделированию систем, связанных с управлением ИД, осуществлено описательными средствами или 
представлены с недостаточной формализацией, и предлагают практически экспериментировать с управлением ИД, избегая возможность оценить результативность и последствия различных вариантов управления ИД в будущей перспективе с минимизацией рисков ИД при принятии управленческих решений. Предметом исследования в статье является инструментарий экономико-математического моделирования развития ИД отечественного агропромышленного производства. Цель заключается в разработке инструментов моделирования развития ИД предприятий АПК Украины в виде аналитических зависимостей факторов влияния. Задача: Исследование динамики развития ИД предприятий АПК Украины в разрезе ее составляющих в условиях глобализации мирохозяйственных процессов на рынке сельскохозяйственной продукции. Используются общенаучные методы: системный анализ - для определения особенностей развития ИД агропромышленного производства Украины, факторный анализ для формализации причинно-следственных взаимосвязей исследуемых факторов влияния на ИД предприятий АПК. Получены следующие результаты: на основе проведенного анализа динамики изменения основных показателей отечественного агропроизводства выявлены проблемные аспекты и определены составляющие ИД агропромышленного производства, вычислены латентные факторы, имеющие пролонгированное влияние на уровень ИД предприятий АПК Украины. Выводы: вычисленные латентные факторы влияния на ИД предприятий АПК целесообразно использовать во внешнеэкономической деятельности в качестве рекомендаций для определения стратегии ИД Украины на мировом рынке сельскохозяйственной продукции.

Ключевые слова: инновационная деятельность, мировое хозяйство, агропромышленное производство, сельскохозяйственная продукция, факторы развития, латентные факторы. 